\title{
Karma Deprem Yalıtım Sistemlerinin Deneysel Performans Değerlendirmesi
}

\section{Experimental Performance Evaluation of Hybrid Isolation Systems \\ Cem Yenidoğan $1^{*}$ (D)}

\begin{abstract}
${ }^{1}$ Bahçeşehir Üniversitesi, İnşaat Mühendisliği Bölümü, Mühendislik ve Doğa Bilimleri Fakültesi, İstanbul, TÜRKIYE Sorumlu Yazar / Corresponding Author*: cem.yenidogan@eng.bau.edu.tr

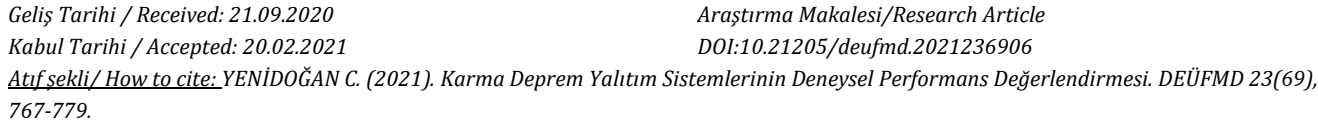

Öz

Deprem yalıtım teknolojisi yer hareketi ile yapısal sistem arasında bir ayrışım yaratarak depremlerin yıkıcı etkilerini azaltmak amacı ile kullanılan yenilikçi bir tasarım ve güçlendirme yöntemidir. Bu çalışma 1/4 ölçekli üç katlı simetrik ve eşmerkezli çelik yapının korunması için önerilen karma yalıtım sistemlerinin sarsma masası deneyleri ile etkinliğinin araștırılması üzerine odaklanmaktadır. Kullanılan pasif yalıtım sistemi, yüksek sönümlü elastomer ve düz yüzeyli sürtünme tipi kayıcı yalıtım birimlerinden oluşmaktadır. Deney programında kullanılan yer hareketi kademeli olarak arttırılarak, yalıtım sisteminde ortaya çlkabilecek davranış farkları araștırılmıștır. Deprem kaydının \%100 etkitildiği durumda daha yüksek kayma modülüne sahip olan elastomer birimlerden oluşan yalıtım sisteminin daha düşük kayma modulüne sahip olan deprem yalıtım sistemine oranla taban kesme kuvveti açısından beklenildiği gibi daha yüksek değerler verdiği gözlenmiştir.

Anahtar Kelimeler: Deprem Yalıtımı, Yüksek Sönümlü Elastomer, Düz Yüzeyli Sürtünme Tipi Yalıtıcı, Sarsma Masası Testleri Abstract

The seismic isolation technology is an innovative design/retrofit method. It decouples the structural response from the ground motion to reduce floor accelerations while concentrating most of the deformation demands at the isolation interface. The main objective of this research study is to investigate the effectiveness of passive-hybrid isolation systems for a $1 / 4$ scaled mass concentric threestory steel structure. The passive-hybrid isolation system is a combination of HDRB and PTFE sliding bearings. The ground motion used in the shake table tests is gradually increased to investigate changes in the dynamic response characteristics of the hybrid isolation system. It has been observed that the isolation system consisting of elastomer units with larger shear modulus subjected to higher base shear with displacement demands than the system with the lower shear modulus.

Keywords: Seismic isolation, HDRB, Flat friction sliders, shake table tests 


\section{Giriş}

Deprem insan hayatını tehdit eden doğal bir afet olması yanında büyük ekonomik kayıplara ve modern hayatın işleyişinde önemli aksamalara neden olabilmektedir. $\mathrm{Bu}$ yüzden, sürdürülebilirlik hedefleri ve depreme dirençli bir toplum yapısının olușturulması ancak sistematik ve bütünsel yaklaşımların uygulanması ile mümkündür. Olası bir depremde mevcut yapı envanteri ve alt yapı sistemlerinde ortaya çlkabilecek hasar dağılımının doğru tespit edilebilmesi, can ve mal kayıplarının azaltılması, geri kazanım adı verilen sürecin kısaltılması ancak afet öncesi stratejik planlama ve doğru afet yönetimi ile mümkündür. Afetlerden önce stratejik planlamada kullanılan envanter, bina hasar görebilirlik çalışmaları ile karar verici mekanizmaya kritik çıktılar sunabilirler $[1,2,3]$. Yapı envanterinde yer alan binalar inșa edildikleri yıllara göre yürürlükte olan yönetmeliklerin dikkatlice ele alınması, yön eylem planın oluşturulmasında oldukça önemlidir. Büyük depremlerden sonra öğrenilen deneyimler ve yapısal performansın daha iyi hale getirilmesi için yürütülen bilimsel araştırmalar, deprem yönetmeliklerinin güncellenmesini veya son șekillerini almalarını sağlamışlardır.

Günümüzde deprem yönetmelikleri ve şartnameler eksiksiz bir şekilde uygulandığında, can güvenliği ve göçmenin engellenmesi performans hedefleri olağan bir durum haline gelebilmektedir. Diğer bir deyișle, geleneksel yöntemlere göre inșa edilen, kapasite tasarım ilkelerinin uygulandığı, yeterli dayanım ve sünekliğe sahip yapılarda, orta ve büyük ölçekli depremler sonrası yapısal kararsızlığa bağlı göçmenin meydana gelmediği, saha incelemeleri ve matematiksel modeller yardımı ile ispatlanmıştır [4]. Fakat çağımızın getirdiği yeni koșullar ve deprem mühendisliğinde yaşanan ilerleme düşünüldüğünde paydaşlar tarafından standart olarak talep edilen can güvenliği performans hedefi yerine daha yüksek performans hedefleri talep edilebilmektedir. Örneğin büyük ölçekli bir deprem sonrasında barınma sorununun ortaya çıkmaması, sanayi yapıları ve is merkezlerinde ekonomik kayıpların asgari seviyede tutulması, hastane, afet yönetim merkezleri gibi önemli yapıların deprem sonrası işlevselliklerinin korunabilmesi aranan yüksek performans hedefleri arasında sayılabilir. $\mathrm{Bu}$ açıdan değerlendirildiğinde deprem yalıtımı getirmiș olduğu esneklik ve ekonomik çözümler ile mühendislere farklı seçenekler sunabilmektedir. Deprem yalıtım sistemleri, geçmişte öncelikle örnek yapılar ve önemli yapılar için tercih edilirken, teknolojinin olgunlaşma evresine girmesiyle birlikte şartnameler ve deprem yönetmeliklerinde binalarda kullanımına dair tasarım yöntemleri, deney protokolleri, kontrol mekanizması için izlenecek kurallar açıklanmıştır. Japon Deprem Yalıtım Derneği tarafından derlenen yalıtımlı bina envanteri pasif kontrol sistemlerinin toplum nezdinde kabulu ve tarihsel gelişimine ışık tutmaktadır. Bu süreçte 1994 Northridge ve 1995 Hyogo Ken Nanbu depremlerinden sonra yalıtımlı bina sayısında ortaya çıkan artıș, bu iki depremin dünya genelinde yalıtım teknolojisine olan ilgiyi hızlandırdığı görülmektedir [5]. Türkiye'de de benzer bir șekilde artan uygulama sayısının bir sonucu olarak deprem yalıtım teknolojisi ve bu teknolojinin binalarda kullanımına dair kurallar 2018-Türkiye Bina Deprem Yönetmeliğinde (TBDY-2018) ayrı bir bölüm olarak yer almıștır[6]. Mühendisler için deprem yalıtımı uygulanmış binaların tasarım ve çözüm kurallarını içeren TBDY-2018'de yer alan yeni bölüm, rehberlik eden bir doküman olması yanında teknolojinin geniş bir mühendis kitlesi tarafından tanınmasına ve uygulanabilecek yöntemlerin anlaşılmasına katkı sağlayacaktır.

Deprem yönetmeliklerinde geleneksel ve deprem yalıtımlı binaların tasarımı ve analizi için yer alan kuralların doğrulanması ve kontrolünde deneysel yaklaşımlar önemli rol oynamaktadır $[7,8,9,10,11]$. Deneysel deprem mühendisliğinde en ideal yaklaşım, yapıların gerçek boyutlarında inşa edilerek, elastik hasar seviyesinden başlayarak elastik-ötesi hasar seviyesine kadar geniş bir bant aralığında incelenmesidir. Japonya ülke olarak deprem konusunda farkındalık seviyesinin yüksek olmasından ve yenilikçi mühendislik yaklaşımları ile gerçek ölçekli deney programlarına öncülük yapmaktadır. Japonya'da yer alan, dünyanın en büyük sarsma masası laboratuvarında ölçeklendirilmeye ihtiyaç duyulmadan, gerçek boyutlarında inșa edilen yapıların performans değerlendirilmesi, yeni teknolojiler ve deprem koruma sistemlerinin tahkikleri bilimsel araştırma programları kapsamında yürütülmektedir (Şekil 1.). Bu önemli çalıșmalar, yapı mühendisliğinde ihtiyaç duyulan gerçek veri ihtiyacının karşılanmasına katkı sağlaması yanında mevcut tasarım 
kurallarının gözden geçirilmesine, çözümlemede daha doğru analitik modellerin kullanımına ve gerekli görüldüğü takdirde yönetmeliklerde yer alan kuralların değiștirilmesine olanak sağlamaktadır.
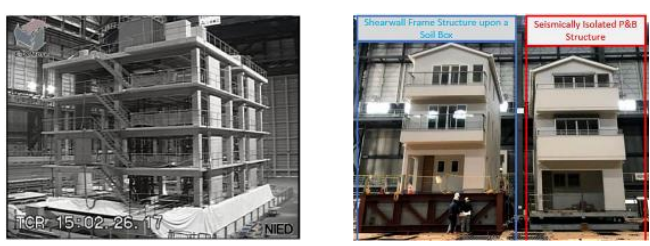

Şekil 1. Gerçek ölçekli betonarme, ahșap ve deprem yalıtımlı ahşap yapı deneyleri $[7,8,9,10]$

Büyük ölçekli sarsma masası deneyleri için inșa edilecek yapıların maliyeti ve sarsma masası laboratuvarının işletim masrafları büyük bütçeler gerektirmektedir. Bu yüzden dünyada kabul görmüş yönetmeliklerin birçoğunda yer alan kurallar genellikle ideal olarak tanımlanan maliyetli deneyler yerine, saha incelemelerinden elde edilen bulgular, matematiksel modeller, ölçeklendirilmiş sarsma masası deneylerine ya da laboratuvarlarda eleman bazlı yürütülen yarıstatik, sözde-dinamik deneylere dayanmaktadır. Türkiye'de deprem davranışı için deneysel çalışmalarda ağırlıklı olarak yarı-statik ve sözde dinamik deney protokolleri kullanılmaktadır. Fakat ölçeklendirilmiș sarsma masası deneyleri benzeșim ilkelerine uyarak etkitilen dinamik yükler altında yapıların genel davranışını daha gerçekçi temsil edebilmekte ve önerilen matematiksel modellerin geçerliliğinin doğrulanmasında tercih edilmektedir.

Türkiye'de deprem yalıtım teknolojisi ile ilgili bilimsel araştırmalar genellikle deneysel çalışmalar yerine sayısal modeller[12] üzerinden gerçekleştirilmektedir. Bu durumun başlıca nedeni ülkemizde sarsma masası test programlarını yürütecek kapasitede laboratuvar sayısının sınırlı olmasıdır. $\mathrm{Bu}$ çalıșma kapsamında deprem yalıtım teknolojisinin binalarda uygulanması için önerilen genel kavramlar tanıtılırken, Türkiye'nin ilk sarsma masası laboratuvarında yürütülen karma yalıtım sistemi deney programının çıktıları paylassılmaktadır. Yüksek sönümlü elastomer birimlerinin özelliklerinden dolayı iki farklı karma yalıtım sistemi, artımsal olarak verilen deprem yer hareketi altında incelenerek performans kıyaslaması yapılmıștır. Yalıtım sistemlerinin genel davranıșının tespiti ve kıyaslanmasında tasarım ölçütleri arasında taban kesme kuvveti, üst yapının hasar dağılımı, kat ivmelerinin değișimi ve yalıtım sisteminin yer değiştirme talepleri temel alınarak bir değerlendirilmeye gidilmiștir.

\subsection{Binalarda Deprem Yalıtım Sistemleri}

Deprem yalıtım teknolojisi yüksek performans hedefi konulan yapılarda, yer hareketi ile yapısal sistem arasında bir ayrışım yaratarak depremlerin yıkıcı etkilerini azaltmak amacı ile kullanılan yenilikçi bir tasarım ve güçlendirme yöntemidir. Geleneksel yaklașımlara göre tasarlanmış olan yapılarda yer değiștirmelerin azaltılması için arttırılan rijitlik, kat ivmelerinde artıșlara neden olurken kat ivmelerinin azaltılması için alınacak önlemler ise izin verilebilir yer değiștirme taleplerinin așılması durumunu ortaya çıkartabilmektedir $[13,14,15]$. Dolayısı ile yönetmelikler ile uyumlu, geleneksel yöntemlere göre tasarlanan binalar için yüksek performans hedefleri amaçlandığında yapısal ve yapısal olmayan hasarın istenilen seviyelerde tutulması ekonomik olmayan çözümler üretebilmektedir. Yüksek performans hedefi konulan binalar arasında yer alan hastane, veri merkezi ve afet yönetim merkezleri gibi özel yapılarda hasarların azaltılmasında olgunlaşma sürecine girmiş olan yalıtım teknolojisi, tasarımcılara yapının servis ömrünü uzatan, ekonomik ve esnek çözümler sunabilmektedir. Fakat günümüzde yalıtım teknolojisinin kullanımı sadece özel yapılarla sınırla kalmayarak binalarda, enerji aktarım sistemlerinde, endüstriyel üretim merkezlerinde, belirli katlarda yer alan verilerin/pahalı teçhizatların ve müzelerde yer alan değerli kültür varlıklarının korunması gibi farklı amaçlara hizmet edebilmektedir $[16,17,18]$. Deprem yalıtım sistemleri inşa edilecek binada veya güçlendirilmesi planlanan mevcut bir binanın özelliklerine göre Şekil 2.'de gösterildiği gibi yapının kilit noktalarına yerleştirilir.

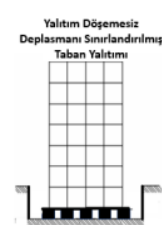

(a)

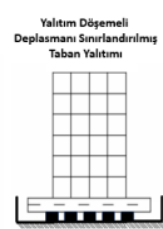

(b)

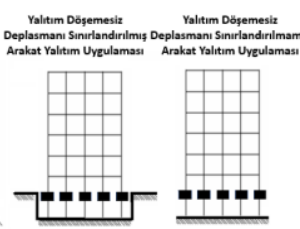

(c) (d)
Şekil 2. Üstyapı özelliklerine göre deprem yalıtım sistemlerinin farklı yerleşim planları 
Yalıtım sistemleri yardımı ile kavramsal olarak yapının hakim doğal titreșim periyodu tehlikeli bölge olarak tanımlanan frekans aralığının dıșına taşınarak yapıya etkiyebilecek tasarım kuvvetlerinin azalımı sağlanabilir. Diğer bir deyişle yalıtım sistemleri yardımı ile yapıya etkiyebilecek muhtemel deprem kuvvetleri azaltılarak yer değiştirme taleplerinin büyük bir bölümü yalıtım katmanında yoğunlaşır. Yapıda tanımlanan yalıtım modunun frekansının rijit bir yapıya göre azaltılması, Șekil 3'te gösterildiği șekilde spektral ivmelerde dolayısı ile

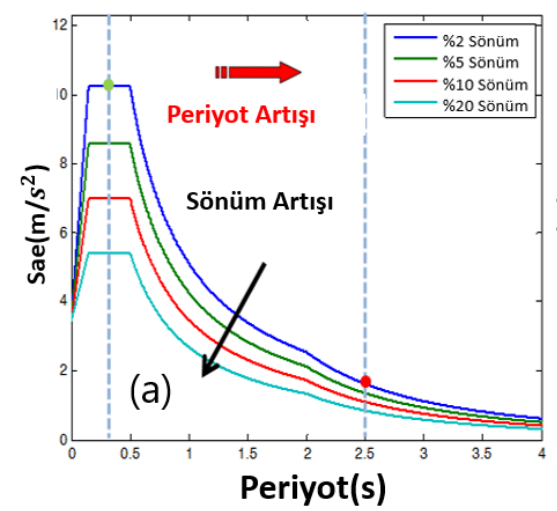

kuvvetlerde azalıma neden olurken aynı zamanda yalıtım birimlerinde yerdeğiștirme taleplerinin artımına neden olacaktır. Yalıtım arayüzünde ortaya çıkabilecek aşırı yerdeğiştirme talepleri yalıtım birimlerinin içinde barındırdığı sönüm özelliklerine veya ek enerji sönümleyici cihazlar ile sınırlandırılabilir. Şekil 3a ve Şekil 3b'de geleneksel bir yapının sadece deprem yalıtım sistemi kullanılarak dinamik davranışının değişimi ile elde edilebilecek kazanımlar deprem davranış spektrumlarında gösterilmiștir.

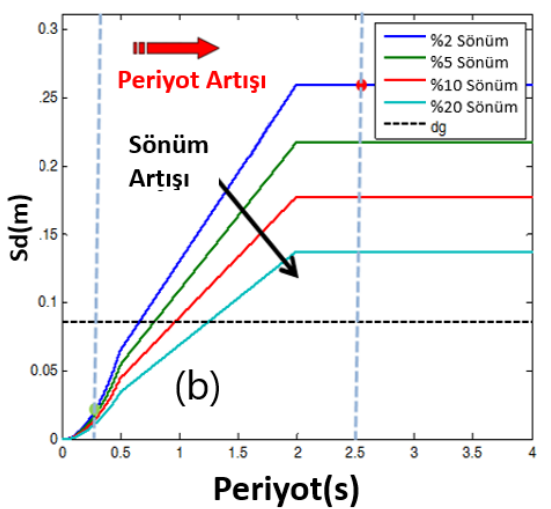

Şekil 3. (a)EC-8 tasarım spektrumuna göre spektral ivme değişimi (b) Spektral yer değiștirme değişimi [18]

Son dönemde konut tipi yapılarda ortaya çıkan deprem yalıtım teknolojisine artan ilginin nedenleri arasında büyük ve orta ölçekli depremlerden elde edilen saha verilerinin artması, malzeme biliminde ve bilgisayar teknolojisinde ortaya çlkan hızlı gelișim sayllabilir. Türkiye'de benzer sebeplere ek olarak, 2013 Sağlık Bakanlığı genelgesinde[19] 2007 deprem yönetmeliğine[20] göre 1. ve 2 . Deprem bölgelerinde yer alan 100 yatak ve üzeri kapasiteye sahip olan hastaneler ve TBDY2018[6] içerisinde ayrı bir bölüm olarak yer alan deprem yalıtımlı bina tasarım ve çözümleme kuralları teknolojinin kullanımı ve yaygınlaşmasında katkı çarpanı etkisi yaratacaktır.

\subsection{Deprem Yalıtım Birimlerinin Özellikleri ve Sayısal Modelleme Yöntemi}

Deprem yalıtım teknolojisi yapıya eklenen cihazlar yardımı ile yukarıda belirtildiği gibi yapının dinamik davranıșında değișimler meydana getirmektedir. Teknolojinin doğru kullanımı öncelikle her bir proje için koyulan performans ölçütlerinin doğru anlaşılarak, yapısal güvenlik ve ekonomi anlamında en uygun koruma sisteminin seçilmesi ile başlar. Uygun yalıtım cihazlarının boyutları ve düzeni seçildikten sonra nihai tasarım ile göreceli kat ötelemeleri, kat seviyesinde oluşan ivmeler, taban kesme kuvveti ve ișlevselliğin önem arz ettiği binalarda yapısal olmayan sistem/eleman hasarları değerlendirilir. Deprem yalıtım sistemleri geleneksel tasarım yöntemleri ile kıyaslandığında, kat ivmeleri ve göreli kat ötelemeleri ile ilgili kazanımlardan ödün vermeden, yüksek performans hedeflerinin ekonomik bir şekilde elde edildiği bir tasarıma olanak sağlayabilir.

Deprem yalıtımı uygulanmış yapılarda, tasarım depremi seviyesinde yapısal hasarın elastik sınırlarda veya akma dayanımının aşıldığı durumlarda ise bu sınırlara yakın bir seviyede kalması önerilmektedir. Yalıtım sistemlerinde kullanılan yalıtım birimleri ideal olarak düşeyde etkiyen kuvvetleri karşılayabilecek yeterli rijitlikte ve yatayda nispeten daha düşük rijitliklere sahip birimlerdir. Araștırma enstitüleri ve özel sektörün araştırma geliştirme laboratuvarlarında yürütülen çalıșmalar 
ekseninde her yll deprem yalıtım birimleri ile ilgili birçok patent bașvurusu yapılmaktadır. Fakat yürürlükte olan deprem yönetmelikleri ve şartnameler genellikle tüm cihazların detaylarına göre hazırlanmaktan ziyade inşaat endüstrisinde yaygın kullanım alanı bulan ve genel davranıșı iki ana kategoride sınıflandırılan kauçuktan üretilen elastomer ve sürtünme tipi kayıcı yalıtım birimleri ile ilgili kuralları içermektedir. Yönetmeliklerde iki ana kategoride sinıflandırılan elastomer ve sürtünme tipi yalıtım birimlerinden beklenen davranış, artan yerdeğiştirmeler altında artan dayanım özelliğine sahip olmasıdır.

\section{Sarsma Masası Deney Programı}

Deprem yalıtım teknolojisinin günümüzde yaygın bir şekilde kabul görmesinde deneysel deprem mühendisliğinde kullanılan sarsma masası deneylerinin önemli katkısı vardır. Deprem yalıtım sistemlerinde hakim olan doğrusal olmayan davranıșın modellenmesi ve kullanılan sayısal modellerin doğrulama çalışmaları yalıtım birimleri için uygulanan testler ve sistem davranışının gerçek deprem yer hareketi altında değerlendirildiği sarsma masası deneyleri ile yürütülmektedir. $\mathrm{Bu}$ tarz çalıșmalarda performans değerlendirilmesinde en doğru yaklaşım, zaman tanım alanında

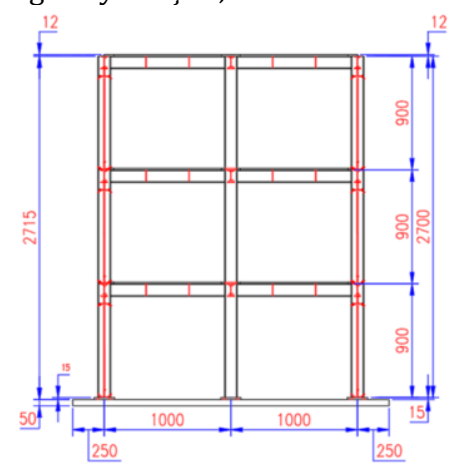

(a)

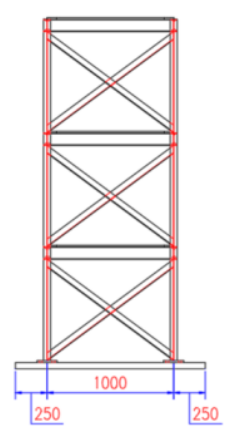

(b) doğrusal olmayan çözümleme için deprem tehlike çalıșmaları ile uyumlu uygun yer hareketi seçimi ve ölçeklendirilmesinin yapılmasıdır.

Kandilli Rasathanesi ve Deprem Araștırma Enstitüsünde (KRDAE) yer alan sarsma masası laboratuvarı düşey yük kapasitesi ve boyutları açısından Türkiye'nin ilk kapsamlı sarsma masası laboratuvarı olma özelliğini taşımaktadır. KRDAE sarsma masası laboratuvarı 2000'li yılların başından başlayarak deprem yalıtım teknolojisi bașta olmak üzere, tarihi yapılar, zemin dayanma yapıları ve yapısal olmayan elemanlara kadar geniş çerçevede deneysel çalışmaların yürütülmesinde etkin bir şekilde kullanılmıştır. $\mathrm{Bu}$ çalışma kapsamında olușturulan sarsma masası deney programında, $1 / 4$ ölçekli karma deprem yalıtım sistemi uygulanmış çelik deney numunesinin dinamik davranıșı ve uygulanan deprem yalıtım sisteminin etkinliği, kademeli olarak arttırılan deprem kayıtları ve harmonik yükleme altında incelenmiștir. Simetrik ve eşmerkezli tasarlanan çelik yapı, yüklemenin yapılacağı yönde çift açıklıklı moment aktaran çelik çerçeveden diğer yönde ise tek açıklıklı ve deprem etkilerinin tamamının süneklik düzeyi yüksek merkezi çaprazlı çelik çerçeveler tarafından karşılandığı bir sistemden oluşmaktadır (Şekil 4.).

Şekil 4. (a)Moment aktaran çerçeve (b) Merkezi çelik çaprazlı çerçeve (c) 3 boyutlu gösterim

Taşıyıcı sistemin deprem yüklerini güvenli ve sürekli bir șekilde aktarabilecek yeterli rijitlik, kararlılık ve dayanıma sahip olmasına dikkat edilmiștir. Karma yalıtım sistemi, üst yapının ve sarsma masasının özelliklerine göre belirlenmiștir. Yalıtım birimi sayısı ve düzeneği belirlendikten sonra prototip deneyleri kullanılarak Şekil 5'te gösterilen üç boyutlu bilgisayar modeli, ticari programlar arasında yaygın kullanım alanı bulan CSI SAP2000[21] ve akademik kullanım amaçlı OpenSees[22] programlarında oluşturulmuştur. Üst yapının dinamik davranış özelliklerini yansıtan bu modelde etkitilecek deprem yer hareketleri incelenerek, yapısal hasarın elastik sınırlar seviyesinde tutulması sağlanmıştır. Ön tasarımda deprem yer hareketinin etkitileceği yönde üst yapının hakim doğal titreșim modu 
0.21 s (Sekil 5a) ve ikinci modu ise 0.68s olarak bulunmuştur. Yapısal sistemin diğer yönde doğal titreşim periyodu (Şekil 5b) ve burulma modu ise $0.057 \mathrm{~s}$ olarak hesaplanmıştır. (a)

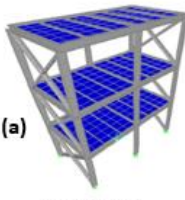

(c)

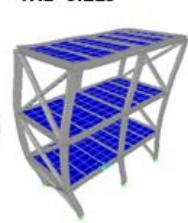

$\mathrm{TX} 2=0.068 \mathrm{~s}$ (b)

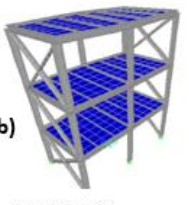

Ty1 $=0.073 \mathrm{~s}$

(d)

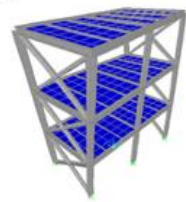

$T \theta 1=0.057 \mathrm{~s}$
Şekil 5. -Çelik yapının titreşim modları

Deney programında araştırılan karma deprem yalıtım sistemi dört sürtünme tipi düz kayıcı yalıtım birimi ve iki yüksek sönümlü kauçuktan oluşmaktadır. Merkezlenme koşulu için deney numunesinin ortasında bulunan kolonların altına yerleștirilen kauçuk elastomerlerin farklı kayma modülüne sahip olması durumunda yapısal performansa etkisi bu çalışmanın inceleme konularından birisi olmuştur. Diğer bir deyișle orta kolonlar altına yerleștirilmiș olan yüksek sönümlü kauçuktan üretilen elastomer mesnetlerin değiștirilmesi ile toplamda iki farklı karma yalıtım sistemi elde edilmiştir. Yüksek sönümlü yalıtım birimleri sistemin merkezlenme koşulunu sağlarken, düz yüzeyli sürtünme tipi kayıcı yalıtım birimleri kauçuk tipi yalıtım birimlerinde ortaya çıkabilecek düssey yüke bağlı sorunları önlemek ve maliyeti düșürmek için Şekil 6.'da gösterildiği gibi yerleștirilmiștir.

Karma Yalıtım Sistemi Plan Düzeni

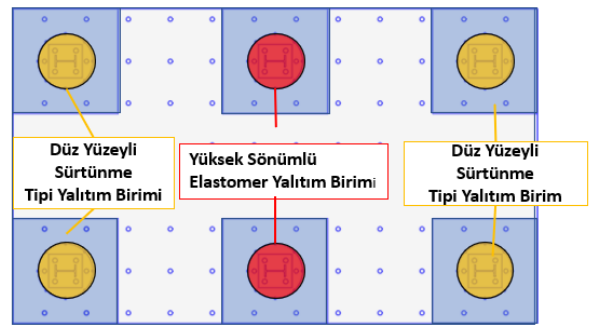

Șekil 6. -Deprem yalıtımlı çelik çerçevenin yalıtım sistemi düzeni

\subsection{Yalıtım Birimlerinin Davranışı}

Deprem yalıtım sistemlerinin 1900'lı yıllardan 2000'li yıllara kadar geçen süreç içerisinde tarihsel gelișimi araștırmacılar tarafından detaylı bir şekilde aktarılmıștır [13,14,15,18,23]. Deprem yalıtım sistemlerinin tasarımında tek serbestlik dereceli veya çift serbestlik dereceli sistemleri temel alan basitleştirilmiş doğrusal(Șekil7c) veya doğrusal olmayan yöntemler(Șekil 8) kullanılabilir. Basitleştirilmiș tek serbestlik dereceli modeller (Şekil 7a.) için Denklem 1.'de verilen hareket denklemi yardımı ile rijit üst yapı kabulüne göre uygun düzenleme ile performans tahkikinde kullanılabilir. Benzer şekilde uygun düzenlemeler yapılarak üst yapının davranışının basitleştirimiş olarak dikkate alındığı çift serbestlik dereceli sistem çözümü (Şekil 7b) ve bu yaklaşım lineer elastik davranış modeline (Şekil 7c) uyarlanabilir.

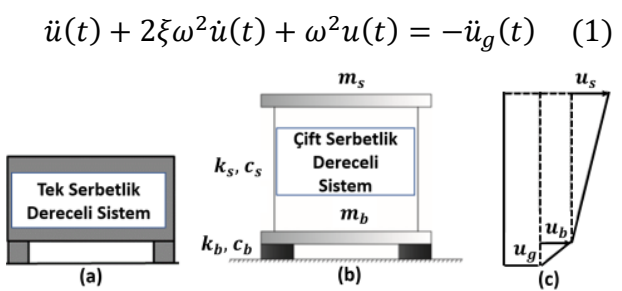

Şekil 7. -Basitleștirilmiş yalıtımlı bina modelleri

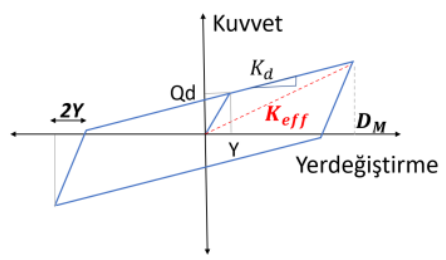

Şekil 8. -İdealleştirilmiş çift eğrili çevrim modeli

Nihai tasarım aşamasında ise yapısal olmayan elemanların korunmasının bir tasarım ölçütü olduğu durumlarda, seçilen doğrusal olmayan yalıtım sistemi ve üst yapının özellikleri yüksek modların etkisi ile değerlendirilebilmelidir. Yalıtım sisteminin, üstyapının davranıșı üzerinde etkinliğinin araștırılması için üç boyutlu yapı modelleri genellikle deprem kayıtlarının iki veya daha fazla yönde etkitildiği durumlarda tercih edilmektedir. Deprem yalıtım birimlerinin yalıtım arayüzü plan yerleșimi, her bir yalıtım biriminin davranışını temsil eden değişkenler ve üstyapı üç boyutlu bilgisayar modeline dikkatlice aktarılmalıdır. Üst yapının rijit kabul edildiği tek moda dayalı analizler, sırası ile üstyapıya etkiyecek en büyük kuvvetler 
ve yalıtım sisteminin en büyük yer değiștirme değerlerinin belirlenmesinde kullanılmaktadır $[18,24]$. Tek modlu eşdeğer deprem yükü yöntemine ek olarak, tek serbestlik dereceli sistemlerin elastik ötesi davranışı için ikinci derece differansiyel denklem, Bouc-Wen modelinin kullanıldığı durumlarda Denklem 2'de gösterildiği gibi düzenlenerek de çözümleme yapılabilir. Denklem 2'de yer alan $T_{d}, Q_{d}, \mathrm{~g}, \mathrm{z}$ deprem yalıtım sistemi periyodu, karakteristik dayanım, yer çekimi ivmesi ve zamana bağlı 0 ve 1 aralığında değişen bir katsayıya karşı gelmektedir.

$\ddot{u}(t)+\left(\frac{2 \pi}{T_{d}}\right)^{2} u(t)+\frac{Q d}{W} g z(t)=-\ddot{u}_{g}(t)$

Sarsma masası deney programında da yukarıda belirtilen yöntemlere göre yalıtımlı bina tasarlanarak, yüksek sönümlü elastomer ve sürtünme tipi yalıtım birimlerinden oluşan iki farklı deprem yalıtım sisteminin performansı değerlendirilmiştir. Kullanılan yalıtım birimlerinin idealize eden davranıș biçimi için kullanılan parametreler, dünyada kabul gören yönetmeliklerde yer alan genel kabullere göre kullanılmıștır[25,26,27,28]. Akma dayanımına karşı gelen yer değiştirme değeri, Denklem 3'te verilen ifade ile bulunmuștur. İfade içerisinde yer alan $\mathrm{t}$ değeri kauçuk tabaka kalınlığıdır. Prototip test verilerinden elde edilen sonuçların elastomer toplam tabaka kalınlığının \%5 ile $\% 10$ 'u arasında değiștiğini temsil etmektedir.

$D_{y}=0.05 \sim 0.1 \sum t$

Şekil 8'de yer alan ve akma dayanımının aşılması durumunda yalıtım sistemi rijitlik değeri Denklem 4'te yer alan ifade ile hesaplanmaktadır. $A_{r}$ yüksek sönümlü elastomerde yer alan ince celik levhalar ile elastomerin birbirine volkanizasyonu ile elde edilen alanı temsil etmektedir. G elastomer mesnetler için deneylerden elde edilen kayma modülünü göstermektedir. $T_{r}$ ise toplam kauçuk kalınlığını ifade etmektedir.

$K_{d}=G A_{r} /\left(T_{r}\right)$

YSE için önemli bir tasarım parametresi olan karakteristik dayanımın hesabında herhangi bir test verisi mevcut değilse FEMA-356[21] içerisinde yer alan Denklem 5 ile de hesaplanabilir. $\beta_{\text {eff }}$ ve $k_{d}$ yalıtım sisteminin etkin sönüm oranını ve elastik ötesi ikincil rijitlik değerini temsil etmektedir.

$Q_{d}=\frac{\pi \beta_{e f f} k_{d} D^{2}}{\left(2-\pi \beta_{e f f}\right) D-2 D_{y}}$

Sarsma masası deneylerinde kullanılan iki farklı tip Yüksek-Sönümlü-Elastomer (YSE) için prototip testlerinden elde edilen yalıtım birimi özellikleri Tablo 1'de özetlenmiștir.

Tablo 1. YSE Birimlerin Özellikleri

\begin{tabular}{lll}
\hline Yalıtım Birimi Değişkeni & YSE-I & YSE-II \\
\hline Yanal Rijitlik(kN/mm) & 0.097 & 0.048 \\
Düşey Yük Kapasitesi (kN) & 27 & 15 \\
Yerdeğiştirme Kapasitesi(mm) & \pm 85 & \pm 55 \\
Kayma Modülü-G(MPa) & $0.8 \mathrm{MPa}$ & $0.4 \mathrm{MPa}$ \\
Toplam Kauçuk Kalınlığı (mm) & 136 & 136 \\
\hline
\end{tabular}

Düz yüzeyli yalıtım birimlerinde deprem yükleri altında dinamik sürtünme katsayısının değişimi Constantinou vd. [29] tarafından önerilen Denklem 6 kullanılarak hesaplanabilmektedir. Önerilen denklem eksenel yükte oluşabilecek değişimleri sürtünme modelinde dikkate almamaktadır. Eksenel yüke bağlı en büyük sürtünme katsayısının değișimi ise Şekil 9'da gösterilmiştir. Denklem 6'da yer alan $f_{\max }$ ve $f_{\min }$ en yüksek ve en düşük sürtünme katsayılarını, $\dot{U}$ hız değerini, a ise $f_{\min }$ ve $f_{\max }$ değerlerine bağlı belirlenen bir değișkeni göstermektedir.

$\mu_{s}=f_{\max }\left(f_{\max }-f_{\min }\right) \exp (-a|\dot{U}|)$

Yürütülen deneysel çalıșmanın ön tasarım aşamasında girdi dosyalarının yaratacağı talep parametrelerinin hesabında, yalıtım birimlerinin üzerinde yalıtım döşemesi kullanılmasından dolayı Şekil 9'da verilen iki sürtünme modelinden sadece hıza bağlı değişimi dikkate alan sürtünme modeli tercih edilmiştir. 
(a)

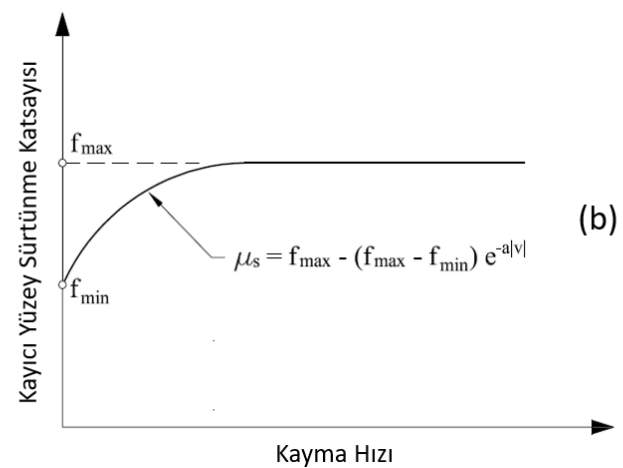

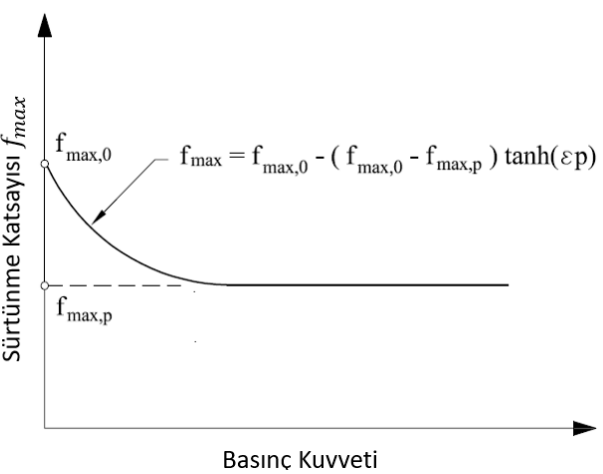

Basınc Kuvveti

Şekil 9. (a) Hız değişimine bağlı sürtünme modeli[29] (b) Hız ve eksenel yükün değişimine bağlı sürtünme modeli[30]

Sürtünme katsayının değișimi yüzeye yağlanma uygulanması veya uygulanmamasına göre \%1.5 ile \%4 arasında değișen değerler aldığ prototip deneylerinde belirlenilmiștir.

\subsection{Sarsma Masası Deprem Kaydı Seçimi}

Sarsma masası deneylerinde girdi olarak verilen deprem kayıtları ile çıktı olarak alınan kayıtların istenilen seviyelerde benzerlik gösterebilmesi sarsma masasından doğru kontrol yöntemlerinin uygulanmasına bağlıdır. $\mathrm{Bu}$ koşulun yerine getirilmesi sarsma masasının ve test edilen üst yapının özellikleri ile yakından ilişkilidir. $\mathrm{Bu}$ çalışma kapsamında seçilen deprem kaydının davranış spektrumu üst

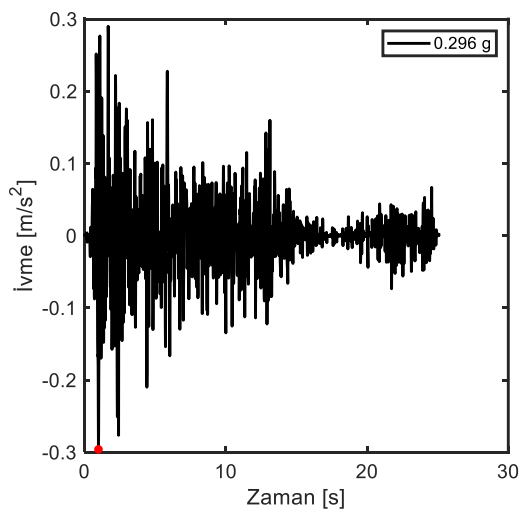

yapının doğal titreşim periyoduna yakın aralıkta en yüksek değerlere karşı gelmektedir. Deney programının amaçları doğrultusunda seçilen deprem kaydına benzeşim kuralları uygulanarak bir ölçeklendirme yapılmıştır. Zaman tanım alanında deprem kaydının değișimi, ivme-hızyerdeğiştirme davranış spektrumları ve frekans içeriği Şekil 10.'da gösterilmiştir. Seçilen deprem kaydı her bir karma yalıtım sistemi için \%20 seviyesinden başlayarak yükseltilerek ortaya çıkabilecek davranış farklılıklarının incelenmesi sağlanmıştır. Artımsal dinamik deneysel analiz için deprem kaydının genlik değerleri, doğrusal olarak bir katsayı ile çarpılarak, deprem kaydının frekans içeriği korunmuştur.
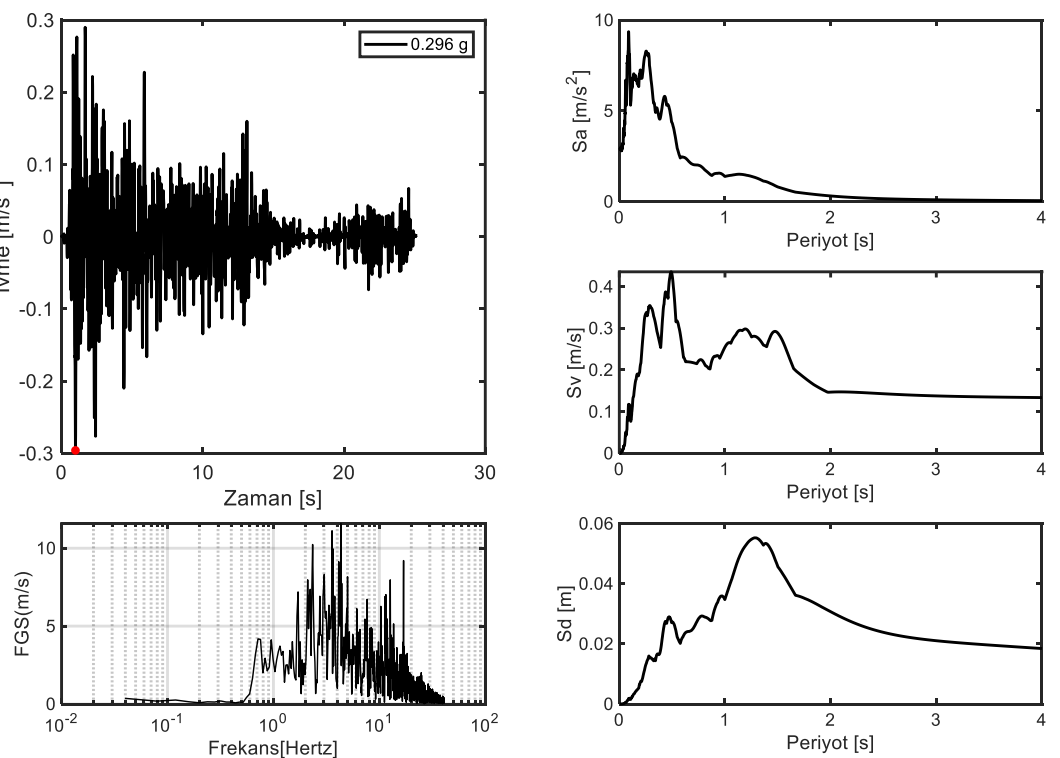

Şekil 10. El Centro kaydının sarsma masası deneyleri için kullanılan girdi dosyası, kaydın frekans içeriği ve davranıș spektrumları 


\section{2. Ölçüm Aletlerinin Yerleşimi}

Sarsma masası deneylerinde ölçüm aletlerinin uygun yerleşimi sistem tanılama çalışmaları için çok önemlidir. Deney programında deprem yalıtım sistemi ve üst yapının dinamik davranışını aynı anda yansıtabilecek şekilde hazırlanan ölçüm aleti yerleşim planı Şekil 11'de gösterilmiştir. (a)

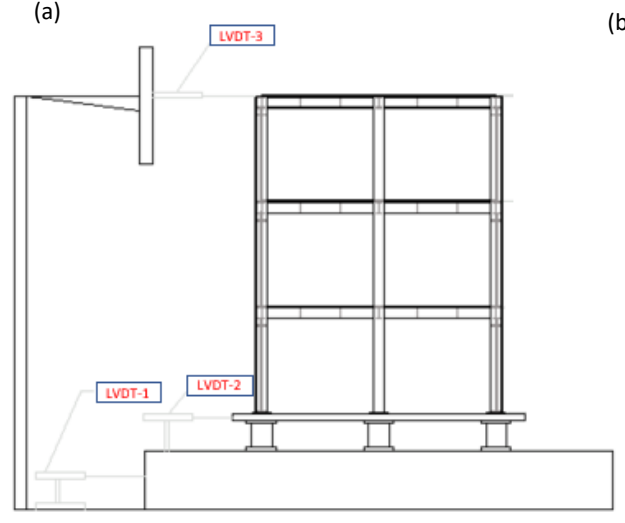

(b)

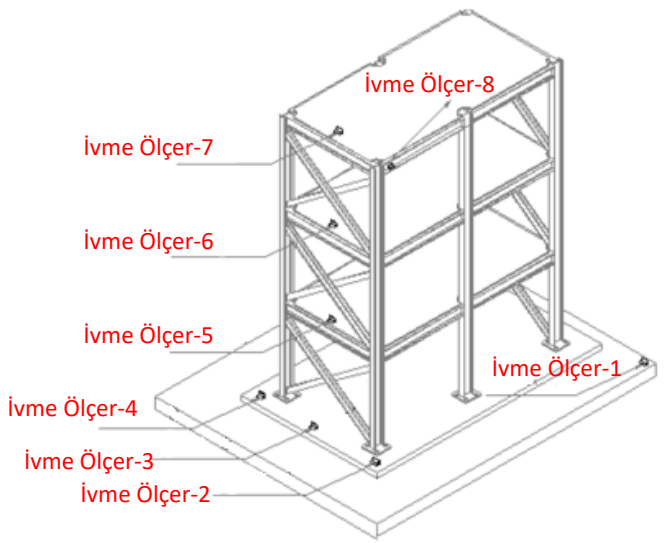

Şekil 11. -Yerdeğiştirme ölçer ve ivme ölçer düzeni

\section{Bulgular}

Deneyler sırasında kaydedilen veriler, uygun filtreleme yöntemleri kullanılarak yapının ilk üç doğal titreşim moduna karşı gelen frekansların tespitinde kullanılmıștır (Şekil 12). İşlenmiş deney verilerinin ve ön tasarımda kullanılan üç boyutlu sayısal modelin yakın değerler vermesi, hem ön tasarım aşamasında doğru bir yaklaşımın uygulandığını hem de bütün deneyler boyunca üst yapının hasar miktarının yalıtımlı binalarda hedeflenen elastik sınırlar içerisinde kaldığını ispatlamıştır. Birinci ve ikinci karma yalıtım sistemleri, deprem hareketi altında elde edilen transfer fonksiyonları karşılaștırıldığında birbirine çok yakın değerler vermiștir.

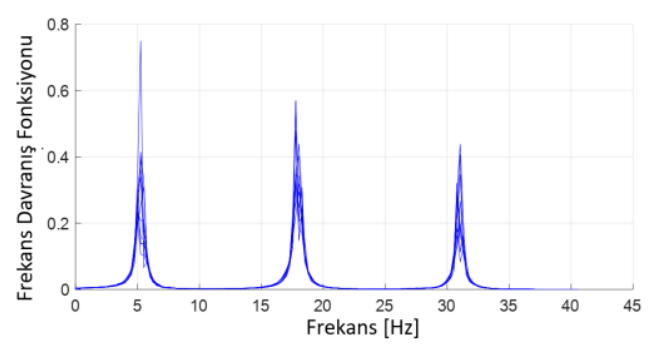

Şekil 12. Deneylerden elde edilen üstyapı titreşim frekansları
Deprem yalıtım sistemlerinin kuvvetyerdeğiștirme eğrileri, yalıtım döşemesinden çatı katına kadar olan her kat seviyesinde elde edilen ivmelerinin zaman tanım alanında değişimi incelenmiştir. Karma Yalıtım Sistemi (KYS)-I için 100\% deprem kaydının etkitilmesi ile elde edilen kuvvet-yerdeğiștirme değişimi ve kat ivmeleri sırası ile Şekil 13-14'te verilmiştir. Elde edilen kuvvet-deformasyon ilișkisi, ulaşılan yerdeğiștirme sınırlarında, değișen anlık rijitlik değerlerine göre visko-elastike yakın bir davranış göstermiştir. KYS-I sistemi için yer hareketinin ve deprem yalıtımı uygulanmış yapının her seviyesinde alınan kat ivmeleri Șekil 14 'te gösterilmektedir.
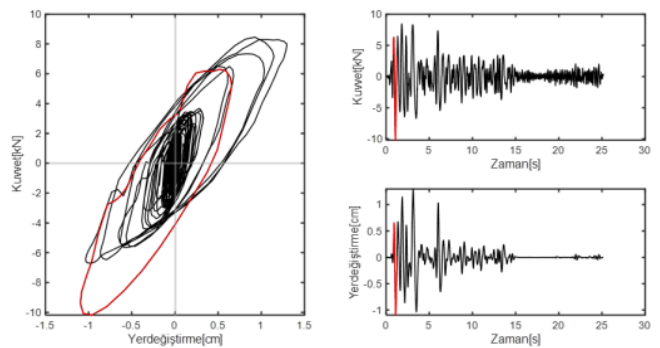

Şekil 13. KYS-I Kuvvet-yerdeğiştirme çevrimi 
Deprem yer hareketinin en büyük ivme değeri $0.296 \mathrm{~g}$ olarak kaydedilirken, çatı katında kaydedilen en büyük kat ivmesi Şekil 14'te

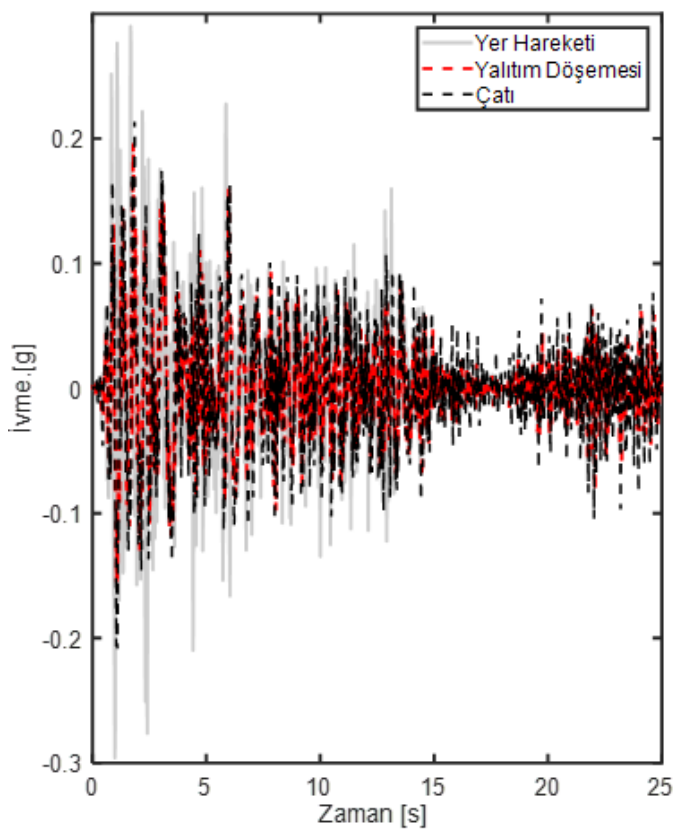

0.213g seviyesinde kalmıs ve geleneksel yöntemlere göre inşa edilecek yapılara göre kayda değer bir azalım sağlanılmıștır.

Şekil 14. KYS-I kat ivmelerinin değişimi

Benzer sekilde KYS-II için 100\% deprem kaydının etkitilmesi durumunda zaman tanım alanında elde edilen kuvvet-yerdeğiștirme çevrimleri ve kat seviyesinde ölçülen ivmeler sırası ile Şekil 15-16'da verilmiştir.
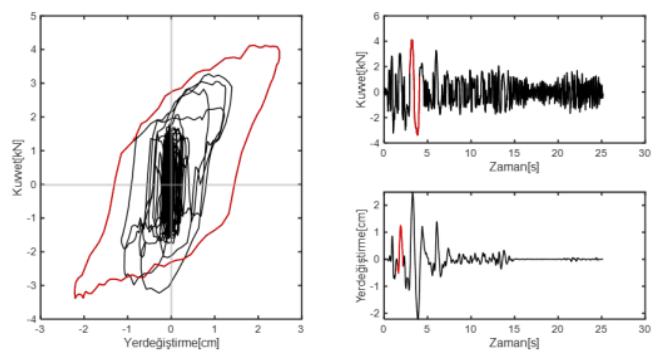

Şekil 15. KYS-II Kuvvet-yer değiștirme çevrimi

Deprem kaydı girdisi ise Şekil 16'da gösterildiği gibi çatı katında $0.135 \mathrm{~g}$ seviyesine düșerken KYS-II sistemi daha düşük kayma modülüne sahip elastomer birimlerden oluștuğu için kuvvet-yerdeğiștirme çevrimleri daha yüksek
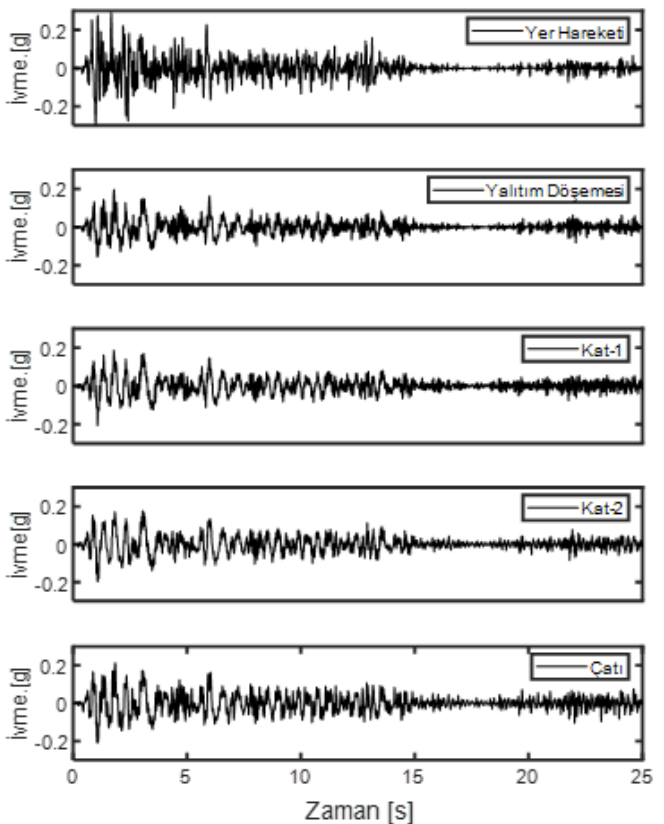

yerdeğiştirme değerlerine ulaşılıp, taban kesme kuvvetinin daha etkin bir şekilde azalımına neden olmuştur. Deney verilerine göre ikinci sistem KYS-I'e göre \%43'ten daha fazla azalım sağlamıştır. Kuvvet-yerdeğiştirme çevrimleri, ulaşılan yerdeğiştirme genliklerinde idealize edilen çift eğrili elasto-plastik çevrimlere benzer davranış göstermektedir.

Sarsma masasında kullanılan deprem kaydı \%20 genlik seviyesinden bașlayarak zaman tanım alanında yapılan artımsal dinamik analiz uygulamasına benzer şekilde deneyde kullanılacak deprem kaydının ölçeklendirme katsayısının doğrusal ve kademeli olarak \%100'seviyesine kadar arttırlarak iki farklı karma yalıtım sisteminin aynı deprem seviyelerinde kiyaslanmasına olanak sağlanmıștır. 

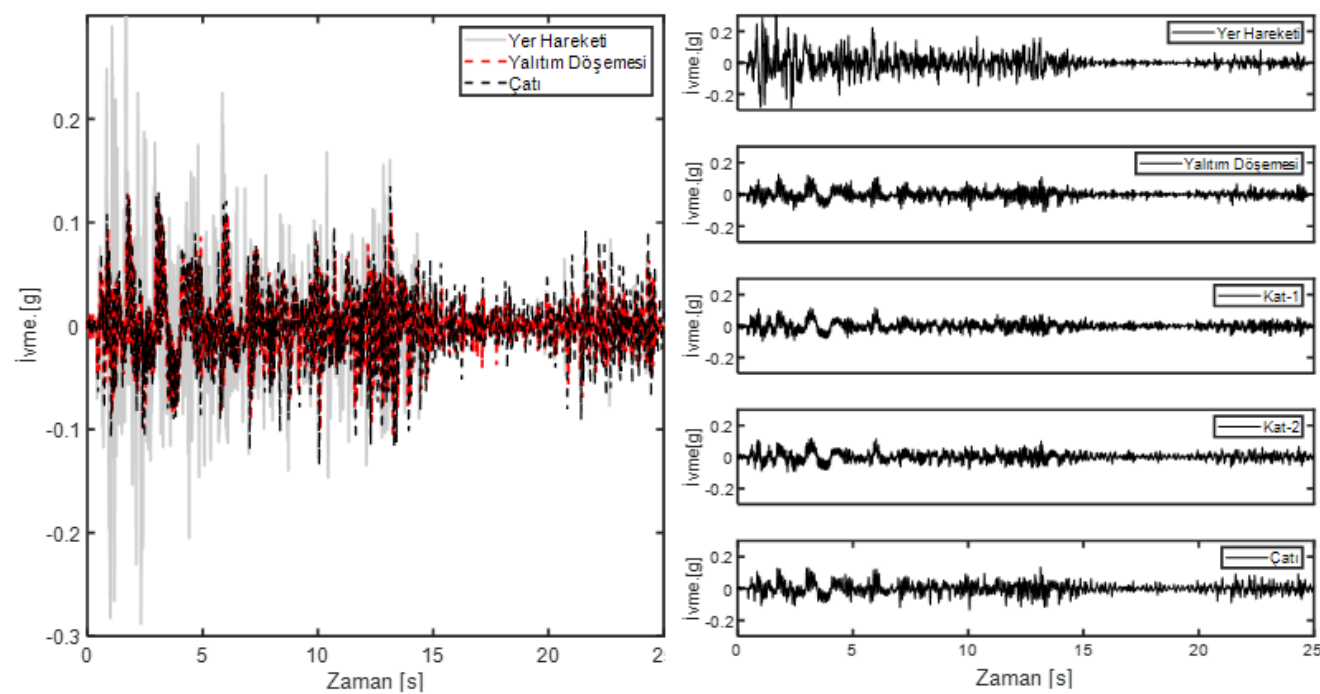

Şekil 16. KYS-II Kat ivmelerinin değişimi

KYS-I ve KYS-II'nin çevrimsel dinamik davranıșı Şekil 17'de verilmiştir. KYS-I için taban kesme kuvvetinin yaklaşı olarak $10 \quad \mathrm{kN}$ seviyesindeyken, KYS-II sistemi için taban kesme

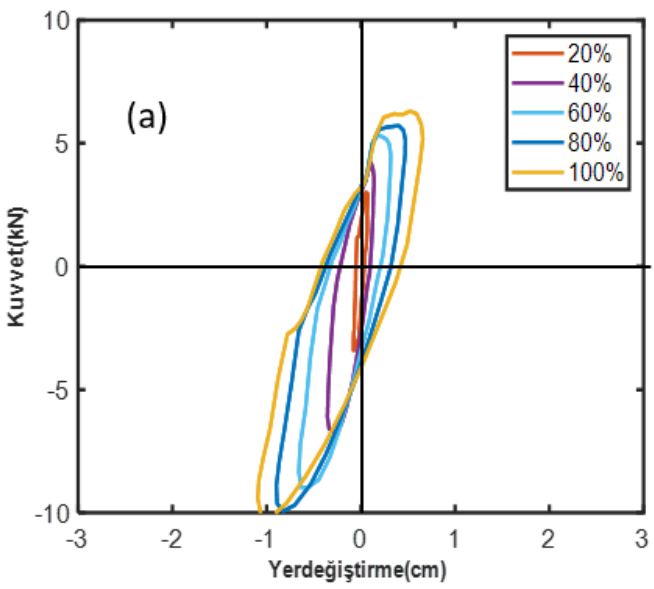

kuvveti $4.1 \mathrm{kN}$ seviyesinde kalması ikinci deprem yalıtım sisteminden elde edilen önemli kazanımlardan bir tanesidir.

Şekil 17. (a)KYS-I dinamik çevrim kıyaslaması (b)KYS-II dinamik çevrim kıyaslaması

\section{Tartışma ve Sonuç}

Deprem yalıtım sistemlerinin genel davranışının anlaşılması ve ihtiyaç duyulan güvenilirlik ve doğrulama çalışmaları deneysel deprem mühendisliğinde önemli bir rol üstlenmektedir. Farklı tip yalıtım birimlerinden oluşan karma yalıtım sistemlerinin pratikte kullanımının

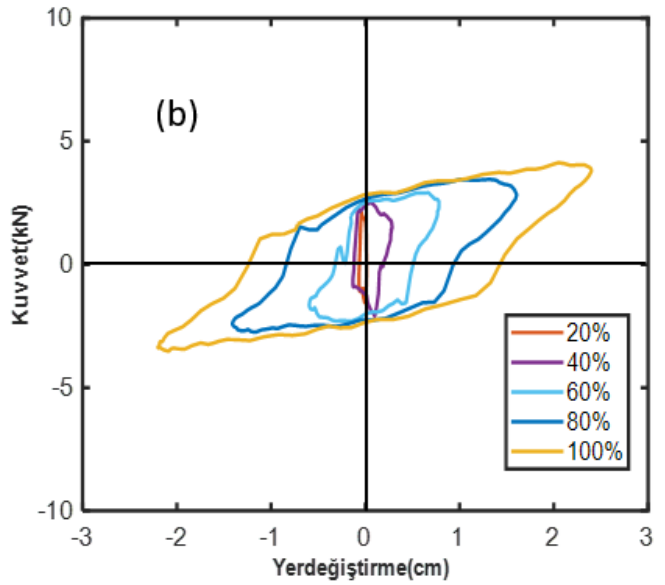

getireceği ekonomik katkı yanında yüksek performans hedeflerine bağlı istenen peformans artım ölçütleri, karma yalıtım teknolojisinin uygulandığı her iki sistem için sağlanmıștır. Diğer bir deyişle, yalıtımlı bina tasarımında öngörüldüğü şekilde üst yapının göreli kat ötelemeleri elastik sınırlarda başarı ile tutulmuştur. 
Sarsma masası deneyinde kademeli olarak arttırılan deprem kaydının yalıtım sistemlerinin kuvvet-yerdeğiștirme çevrimlerinde ortaya çıkan farklılıklar ve üst yapı davranıșı her bir deney kademesi için detaylı olarak yazar tarafından incelenmiștir. Yüksek sönümlü elastomer yalıtım birimlerinden daha düșük kayma modülüne sahip olan ve KYS-II olarak adlandırılan düzenekte taban kesme kuvvetleri birinci sisteme göre yanal rijitlik farklılıklarına bağlı olarak daha etkin bir azalım sağlamıștır. $\mathrm{Bu}$ çalışmada yürütülen deney programının detayları ve işlenen deney verileri doğrultusunda karma yalıtım sistemlerinin etkinliğine dair bulgular okuyucu ile paylaşılmıştır.

Yürütülen deneysel çalışma kapsamında kullanılan sarsma masasının özelliklerinden

\section{Teşekkür}

Çalışmanın dinamik karakterizasyon çalışmaları yazarın yürütücüsü olduğu Bahçeşehir Üniversitesi tarafından desteklenen BAP 2020.01.06 Nolu proje kapsaminda desteklenmiştir. Yazar değerli görüşleri ve katkılarından dolayı Prof. Dr. Eren Uçkan'a, Dr. Yavuz Kaya'ya, testin gerçekleștirilmesinde yardımcı olan Kandilli Rasathanesi ve Deprem Araştırma Enstitüsü Deprem Mühendisliği çalışanlarına, yalıtım cihazlarının tedariğini sağlayan FIP Industrial firmasına, FIP Industrial firmasının Türkiye temsilcisi Yüksek Mühendis Mircan Kaya'ya, FIP Industrial İtalya kıdemli teknik ofis mühendislerinden ve araștırmacılarından olan Dr. Gabriella Castellano'ya ve makalenin kalitesinin yükseltilmesinde değerli yorumlarını paylaşan anonim hakemlere teşekkür eder.

\section{Kaynakça}

[1] Hancilar, U., Tuzun, C., Yenidogan, C., and Erdik, M. 2010. ELER software - a new tool for urban earthquake loss assessment, Natural Hazards Earth System. Sci., 10, 2677-2696, doi: 10.5194 /nhess-102677-2010

[2] Erdik, M., Sesetyan, K., Demircioglu, M.B., Hancilar, U., Zulfikar, C., Durukal, E., Kamer, Y., Yenidogan, C. Tuzun, C., Cagnan, Z., Harmandar, E. 2010. Rapid Earthquake Hazard and Loss Assessment for EuroMediterranean Region, Acta Geophysica, vol.58, no.5, pp: $855-892$

[3] Multi-hazard Loss Estimation Methodology Earthquake Model Hazus MHMR4 Technical Manual, Department of Homeland Security Emergency Preparedness and Response Directorate FEMA Mitigation Division, 2003 dolayı, deprem kayıtları sadece tek bir yönde ve belirli sınırlamalara tabi olarak verilebilmiștir. $\mathrm{Bu}$ yüzden elde edilen deneysel verilerin, ilerleyen çalışma safhalarında sayısal model doğrulamasının basitleştirilmiş modeller ve her bir cihazın ayrı ayrı incelendiği üç boyutlu karmașık modellerle kıyaslanması, öngörülen deprem seviyesinin ötesinde deprem kayıtlarının her iki yatay yönde uygulanması, deprem tehlike çalışmalarında önerilmesi durumunda ise deprem kayıtlarının düşey bileșenin birlikte etkitilmesinin yaratacağ etkilerin araştırılması gerekmektedir. İlerleyen süreçte yapılması planlanan yukarıda sıralanmıș çalışmalar, pratikte yürütülebilecek optimizasyon çalıșmaları için önemli kaynaklardan biri olabilecektir.

[4] Di Sarno, L., Yenidogan, C., Erdik, M. 2013. Field evidence and numerical investigation of the $\mathrm{Mw}=7.1$ October 23 Van, Tabanlı and the MW > 5.7 November earthquakes of 2011, Bulletin of Earthquake Engineering, 11:313-346. DOI: 10.1007/s10518012-9417-0

[5] Kani N. Current 2009. State of Seismic Isolation Design, Journal of Disaster Research; 4(4):175-181.

[6] Türkiye Bina Deprem Yönetmeliği, TC İçişleri Bakanlığı AFAD Afet ve Acil Durum Yönetimi Başkanlığı, Resmi Gazete No.: 30364, 2018

[7] Yenidogan, C., Yokoyama, R., Nagae, T., Tahara, K., Tosauchi, Y., Kajiwara, K., Ghannoum, W. 2018. Shake table test of a full-scale four-story reinforced concrete structure and numerical representation of overall response with modified IMK model, Springer, Bulletin of Earthquake Engineering, Cilt 16 s. 2087-2118. DOI: 10.1007/s10518-017-0261-0

[8] Nagae, T., Uwadan, S., Yenidogan, C., Yamada, S., Kashiwa, H., Hayashi, K., Takahashi, T., Inoue,T., 2021. The 2019 full-scale shake table test program of wood dwellings, 17th World Conference on Earthquake Engineering, 17WCEE, September 27 to October 2, Paper No. C002274.

[9] Yenidogan, C., Takahashi, T., Nagae, T., Inoue, T. 2021. Seismic Performance Evaluation of a Base Isolated P\&B Structure Through Full-Scale Shake Table Tests, 17th World Conference on Earthquake Engineering, 17WCEE, September 27 to October 2, Paper No. C002274.

[10] Yenidogan, C., Nishi, R., Nagae, T., Koichi Kajiwara, 2020. Full-scale cyclic test of a Japanese post and beam wood shearwall assembly, Bull Earthquake Eng Cilt 18, 4985-5008.

[11] Yenidogan C., Nishi,R., Uwadan, S., Nagae, T., Isoda,H., Tsuchimoto,T., Inoue,T., Kajiwara, K.2021.Full-scale shake table tests of P\&B type of Japanese three-story wood dwellings for the collapse characterization, Soil Dynamics and Earthquake Engineering, Vol. 150, 1-22. DOI: 10.1016/j.soildyn.2021.106898 


\section{DEÜ FMD 23(69), 767-779, 2021}

[12] Aydin E.R., Ozturk B., Kilinc O.F. Seismic Response of Low-Rise Base Isolated Structures. In15th World Conference on Earthquake Engineering, Portugal 2012 Vol. 24, pp. 19493-19502

[13] Kelly JM. 1997. Earthquake-Resistant Design with Rubber. Springer-Verlag London Limited, 243s.

[14] Naiem, F. and J.M. Kelly, 1999. Design of Seismic Isolated Structures. Wiley; HAR/CDR Edition John Wiley \& Sons, New York, 304s.

[15] Skinner, R.I., W.H. Robinson, and G.H. McVerry, 1993. An Introduction to Seismic Isolation, John Wiley\& Sons, New York, 354s.

[16] Xuan, D., Pavel, C., Wang, SJ, Medel, RA, Smirnov, V., Yenidogan, C., Forni, M., Aiken, I. 2016. Recent Information on Seismically Isolated Buildings in the World, Journal of Japanese Society of Seismic Isolation "MENSHIN", May, 2016.

[17] Yenidogan, C., Erdik, M. 2014. The State of Art in Seismic Isolation and Energy Dissipation Applications in Turkey, The Japan Society of Seismic Isolation, Menshin Cilt 83, 49-59, 2014-02.

[18] Yenidogan, C. 2021. Earthquake-Resilient Design of Seismically Isolated Buildings: A Review of Technology, Vibration, Cilt 4, no. 3, s. 602-647. DOI: 10.3390/vibration4030035

[19] Türkiye Sağlık Bakanlığı, Deprem Yalıtımlı olarak İnşa Edilecek Yapılara Ait Proje ve Yapım İşlerinde Uyulması Gereken Asgari Standartlar, 2013.

[20] Deprem Bölgelerinde Yapılacak Binalar Hakkında Yönetmelik,Resmi Gazete No.: 26454, 2007

[21] CSI SAP2000V22. Analysis Reference Manual. CSI: Berkeley (CA, USA): Computers and Structures Inc. 2020.

[22] Mazzoni S, McKenna F, Scott MH, Fenves GL. OpenSees command language manual. Pacific Earthquake Engineering Research (PEER) Center. 2006 Jul 19;264.

[23] Basu, B..,Bursi, O. S.,Casciati, F.,Casciati, S.,Del Grosso, A. E.,Domaneschi, M.,Faravelli, L.Holnicki-Szulc, J.,Irschik, H.,Krommer, M.,Lepidi, M.,Martelli, A.,Ozturk, B.,Pozo, F.,Pujol, G., Rakicevic, Z. and Rodellar, J.(2014),A European Association for the Control of Structures joint perspective. Recent studies in civil structural control across Europe,Struct. Control Health Monit.,21:1414-1436. DOI:10.1002/stc.1652

[24] Yenidogan, C and Mustafa E. 2016. A comparative evaluation of design provisions for seismically isolated buildings, Soil Dynamics and Earthquake Engineering, Cilt 90, s. 265-286. DOI: 10.1016/j.soildyn.2016.08.016

[25] Prestandard and Commentary for the Seismic Rehabilitation of Buildings, FEMA 356, 2000 Prepared by the American Society of Civil Engineers for the Federal Emergency Management Agency, Washington, D.C. pp. 100-400.

[26] Minimum Design Loads and Associated Criteria for Buildings and Other Structures ASCE/SEI 716 , American Society of Civil Engineers, 2017.

[27] CEN, Eurocode 8: design of structures for earthquake Resistance-Part 1: general rules, seismic actions and rules for buildings. EN 1998-1:2004. Comité Européen de Normalisation, Brussels, 2004.
[28] Japanese Ministry of Land, Infrastructure and Transport, Notification No. 2009-2000, Technical Standard for Structural Specifications and Calculation of Seismically Isolated Buildings. (in Japanese). 2000.

[29] Constantinou, M.C., Tsopelas, P., Kasalanati, A., and Wolff, E.D. 1999. Property modification factors for seismic isolation bearings. Report MCEER-99-0012, Multidisciplinary Center for Earthquake Engineering Research, State University of New York.

[30] Tsopelas, P.C., Constantinou, M.C. and Reinhorn, A.M., 1994. 3D-BASIS-ME: Computer program for nonlinear dynamic analysis of seismically isolated single and multiple structures and liquid storage tanks. 